\title{
Supernatural sources of martial power: a cross-cultural investigation
}

\author{
Jared MIRACLE* \\ Department of Anthropology, Texas A\&M University (United States)
}

Recepción: 10/02/2014; Aceptación: 11/04/2014; Publicación: 14/04/2014.

\begin{abstract}
This paper utilizes a cross-cultural comparison model of cultural inquiry to approach the question of whether or not there are generalizable trends in the intersection of fighting arts and cultural conceptions of the supernatural. The methods are outlined and background presented to explain how the investigation was undertaken. Sources are limited to the eighteenth and nineteenth centuries and bounded geographically. The regions included are the Japanese archipelago, China, the Afro-Atlantic, the Great Plains of North America, and the Indian subcontinent. The five regions were chosen at random and do not represent an attempt to be comprehensive. Explanation of the evidence is followed by a comparative discussion. While further study is required, the most apparent tentative conclusion is that cultural understanding of supernatural intervention combines with the martial arts in cases where not only physical, but socio-political power is sought in asymmetrical conflict.
\end{abstract}

Keywords: Martial arts; cross-cultural; Boxer Rebellion; Afro-Atlantic; sohei; Dog-Men Society; anthropology.

\section{Fuentes sobrenaturales de poder marcial: una investigación transcultural \\ Resumen}

Este trabajo utiliza un modelo de investigación cultural de comparación transcultural para abordar la pregunta de si existen o no tendencias generales en la intersección de las artes de combate y las concepciones culturales de lo sobrenatural. Se presentan los métodos y los antecedentes para explicar cómo se abordó la investigación. Las fuentes utilizadas se limitaron a los siglos XVIII y XIX, y también se limitaron geográficamente. Las regiones que se incluyeron fueron el archipiélago japonés, China, África atlántica, las grandes llanuras de Norteamérica y el subcontinente indio. Las cinco regiones fueron elegidas aleatoriamente, sin que se tuviese la intención de ser exhaustivos. A la explicación de las evidencias halladas se suma una discusión en términos comparativos. A pesar de son necesarias más investigaciones, la conclusión provisional más evidente es que la comprensión cultural de la intervención sobrenatural se combina con las artes marciales en casos donde no solo se busca el poder físico, sino también el poder socio-político en conflictos asimétricos.

Palabras clave: Artes marciales; transcultural; Rebelión Bóxer; África Atlántica; sohei; Sociedad de los HombresPerro; antropología.

\section{Fontes sobrenaturais do poder marcial: uma investigação transcultural}

\section{Resumo}

Este trabalho utiliza um modelo de investigação cultural de comparação transcultural para reflectir sobre a pergunta se existe ou não tendências gerais na intersecção das artes marciais de combate e as concepções culturais sobre o sobrenatural. Apresentamse, de seguida, os métodos e os antecedentes para explicar como se abordou a investigação. As fontes utilizadas limitaram-se aos séculos XVIII e XIX e também se limitaram geograficamente. As regiões que se incluíram foram o arquipélago japonês, China, África atlântica, as grandes planícies Norte-americanas e o subcontinente Índio. As cinco regiões foram seleccionadas aleatoriamente, sem que se tivéssemos a intenção de ser exaustivos. As explicações das evidências foram chamadas a discussão em termos de comparação. Apesar de provisória, a conclusão mais evidente é a de que a comparação cultural da intervenção do sobrenatural se combina com as artes marciais, nomeadamente nos casos onde no terreno se procura o poder físico, mas também o poder sociopolítico em conflitos assimétricos.

Palavras-chave: Artes marciais; Transcultural; Rebelião Boxe; África atlântica; Sohei; Sociedade dos Homens-Cães; Antropologia.

*Email: jaredmiracle@tamu.edu. Address: Department of Anthropology. Texas A\&M University. College Station, TX 778434352 (United States). 


\section{1.- Introduction}

In this paper I compare the beliefs and historical practices regarding supernatural sources of martial power in a few cultures at various times in history. For the sake of brevity in comparison, samples are restricted to the eighteenth and nineteenth centuries. This is an effort to apply the qualitative approach to cross-cultural research of social phenomena illustrated by Gump's (1994) work while also reconciling it with Said's (1994) point that labeling ideas may not work well in such a context. Consequently, the results are inconclusive. In this case 'cross-cultural' refers to "systematic comparisons that explicitly aim to answer questions about the incidence, distribution, and causes of cultural variation" (Ember \& Ember, 2001, p. 2). Given the difficulty inherent in merging the cross-cultural approach with Said's focus on essential cultural idiosyncrasy, the most efficacious explanatory social mechanism found is that of socio-political power. Cross-culturally, then, the martial arts are utilized not only for the purpose of physical combat, but also as tools of social control.

\section{2.- Methods and background}

In his classic Orientalism, Edward Said argues that, among other factors, the Western academic compulsion to categorize any and every aspect of the world and the hegemony with which that compulsion has been carried out is, in many ways, a primary contributing factor to the current social and political disputes between Western and non-Western nations (1994, p. 119). To extend this idea further, it is apparent that the rigidity with which these categories are applied has caused certain patterns and connections to be overlooked, especially in terms of less well-studied areas of culture-the martial arts in this case.

Gump notes that regions of conflict between socio-political powers (what he terms "the frontier") often experience a similar series of events as the tension between the two groups is negotiated through violence $(1994$, p. 1). His study focuses on the relationship between imperial and relatively low-power forces, but certainly seems to apply on a broader scale, serving to illustrate one type of scenario in violent conflict. While Gump's premise of a comparative study is useful, the present concern goes beyond initial bloodshed and questions the role of skills of physical conflict resolution among various cultures at various times. This goal is confounded by the unique nature of all ethnographic data. As Ember and Ember (2001) point out, the best for which one can hope in such second-hand, historically-based research is to locate sufficient cultural parallels as to make some generalizable statements (p. 5). They also note the centrality of choosing the correct "metric" by which the parallels can be related to one another, therefore some definition of terms is in order (p. 37).

The martial arts are a social phenomenon distinct from warfare. Green provides a malleable attribute of the former ("social tools") as well as a more specific reference to Scott's 1985 work, "weapons of the weak" (Green, 2003, p. xi-xiii). More pragmatically, it will be useful to say that martial arts are "systematic bodies of knowledge, belief, and practice that are associated with methods of attack and defense against human adversaries and their extrahuman allies" (Green \& Svinth, 2010, p. 331). Alternatively, they may be understood as "systems that blend the physical components of combat with strategy, philosophy, tradition, or other features, thereby distinguishing them from pure physical reaction" (Svinth, 2010, p. xix).These complementary definitions are helpful not only in that they encompass traditions of both military and non-military origin, but also the dimension of extrahuman involvement.

For this argument, the concept of martial arts as tools for social change goes hand-in-hand with the idea that "at one time or another, most major cultures have conceived martial art as a religious duty... religious motivation generally includes the belief that the Deity will grant victory to the person or side that is divinely guided" (Svinth, 2010, p. xxi). While they reference religion specifically, the value of non-mainstream, non-classical spiritual and supernatural traditions will be considered here given that "what we think determines how we see the world around us and invisibly influences our political and personal choices. Rumors and legends affect how we live our lives" (Fine \& Ellis, 2010, p. 1-2). Returning to Said's point that not all cultures institute the same categorizations, this is especially important to keep in mind. 
Like Gump, Galbraith (1982) illustrates the incredible similarities among peoples in conflict with conquering Western powers (p. 133). In all of his examples, the central driving force is reliance on the supernatural to aid in accomplishing the goals of the subjugated. Strong evidence is present that "the Sioux, Xhosa, Zulu, and Maori movements all were manifestations of great travail, of despondency at the seeming impossibility of relief from deprivation through human means" (p. 133).

The individuals involved in these movements were certainly not all untested and untrained. Indeed, the Zulu managed victory over technologically superior British forces at Isandlwana. The Maori, though also outgunned, impressed the British with their courage and skill in combat (Galbraith, 1982, p. 123). In other locations, such as Japan, Western conquerors were not present and the groups coming to blows were less unevenly matched, yet, as will be seen presently, the supernatural was called upon to aid the efforts of skilled combatants. Further, such requests for supernatural intervention have not been limited to large-scale conflict. Extrahuman power is employed in individual combat, both ritual and non-ritual, and in some cases such entities act regardless of human requests.

The cross-cultural comparative method, then, requires that such nonscientific matters as political turmoil be measurable against one another, and for that reason Green and Svinth's qualities of the martial disciplines will be adhered to because, as Ember and Ember (2001, p. 37-38) discuss, when precision is not possible, reliability is the next most valuable feature of a measurement device. Written accounts of martial arts are sought out-preferably from firsthand, ethnographic accounts and traditional narratives, though such material is not always available depending on the timeframe and geographic region-and mined for references to the application or intervention of extrahuman forces alongside or as a proxy for martial arts. The context in which these accounts are situated is then taken into consideration and compared with that of other cultures within the eighteenth and nineteenth centuries. Conclusions are drawn based on those events, qualities, and applications of supernatural martial power that roughly correlate.

\section{3.- Findings}

\section{1.- Japan}

One of the most popular characters in Japanese legend is a warrior-monk named Saito no Musashibo Benkei. According to one version of the story (Klapp, 1954, p. 29), Benkei was a monk of formidable stature and martial ability who set for himself a mission to gather 1,000 swords, which he intended to melt and reshape into a temple bell. Having defeated 999 men, he issued his final challenge at a bridge and was shocked to find himself soundly beaten. The warrior who did so was the prodigious Minamoto no Yoshitsune, whose exploits and tragic life are the stuff of theater productions and television specials (p. 29).

Benkei was so impressed that he-like Robin Hood's Little John-swore his life to the service of Yoshitsune, thereby guaranteeing his position in Japanese lore as a personification of loyalty and dedication. This is the lens through which the real people called sohei, warrior-monks, are often viewed. The sohei are of significant historical importance both politically and militarily; they often came to the aid of the factions that best served their interests (Adolphson, 2007, p. 9). Given their influence on the formation of Japan and the formation of a national identity during the eighteenth and nineteenth centuries, it seems axiomatic to question how Buddhist monks could justify engaging in violence. The answer to this question requires some further discussion of what constituted a monk at the time of the sohei.

The term sohei did not enter the general lexicon until the eighteenth century, by which time (again, like Robin Hood) a trope of the fierce warrior monk had come to be especially associated with the Benkei character. Adolphson points out that, while contemporary records refer to the forces as "monks," the term was used loosely for anyone whose professional activities caused him to be a member of a given temple $(2007$, p. 57). This meant that the body of people who could be accurately described as "monks" was sizeable. At times even those whose full-time occupation revolved around warfare and political intrigue took vows, such as the daimyo Uesugi Kenshin. Adolphson argues that religious justification was not necessarily central to the activities of the sohei 
(p. 57-58). Indeed, it would seem that, when necessitated by political conflict, some monastic orders operated less like societies for spiritual development and more like conscripted armies.

It is apparent that the mainstream Japanese Buddhist traditions, even when engaged in physical confrontation, do not provide a clear link between the spiritual or supernatural realms and achievement of martial power. Instead, more direct connections can be found by turning to less conventional sources. One useful resource in that vein is Hirata Atsutane's Senkyo ibun, a work that Wilburn Hansen characterizes as an "ethnography of the other world" (Hansen, 2008). In 1822 Atsutane, a Shinto theologian and nationalist scholar, met a homeless teenager named Kozo Torakichi, who claimed to be a mountain goblin's apprentice. The two engaged in a lengthy dialogue about the boy's life and exploits among the teng ${ }^{1}{ }^{1}$, resulting in an impressively detailed account.

The importance of Atsutane's work is not solely as a collection of folklore from a homeless adolescent, but as an expression of nationalistic spirituality. The author is best known for his contributions to a field called kokugaku, or nationalist studies. His discussions with Torakichi often indicate that he was attempting to reconcile his own conceptions of the spiritual realm (as determined by a nationalistic brand of Shinto) with the stories that the boy related (Hansen, 2008, p. 3). While certainly not representative of all Japanese at the time, Atsutane's interpretations of the tengu realm, rife with masters of the martial arts, magic, and exploits among menacing, unknown foreigners, provide something of a window into the zeitgeist, for which it is apparent that the fighting arts were a tool used to waylay fears regarding foreign supremacy.

With regards to premodern times, it is apparent that Shugendo, the belief system inextricably attached to the tengu, is also permanently intertwined with the classical martial arts. Say historian Karl Friday and Seki Humitake:

\begin{abstract}
Warriors appear to have begun adapting the methods of religious ascetics to their own purposes by the early sixteenth century. From the use of spiritual exercises to enhance one's fighting ability, it would have been but a short step to the insight that the process could also work the other way around-that study of the bugei $^{2}$ could itself be a means of spiritual discipline (Friday \& Seki, 1997, p. 16).
\end{abstract}

It is little surprise, then, that popular depictions of tengu have them dressed in the garb of Shugendo ascetics. Knutsen (2011) addresses the legend in which Minamoto no Yoshitsune is banished to Mt. Kurama at a young age and there supposedly receives the tengus' instruction in the martial arts (p. 113-114). This story is well-known and the local merchants at Mt. Kurama have, in recent times, taken advantage of the association; shops all around the foot of the mountain sell tengu paraphernalia and the train station features an enormous mural of Yoshitsune and the mountain goblins engaged in fencing practice.

At this point an aside is necessary to address the analytical material in question. While Knutsen's work is valuable as a collection of the points at which the combat arts intersect with the supernatural, he also promotes a dubious hypothesis on the origins of both tengu and the martial arts of Japan, the foundation of which requires: that ancient Central Asians generated griffin iconography after coming across fossilized protoceratops ${ }^{3}$ skulls $(2011$, p. 53), that early shamans in Japan transformed the griffin iconography to match artistic conceptions of the ever-present crows (p. 54), and that sufficient quantities of psychotropic material were consumed so as to provide supernatural revelations, which were then passed down in both religious and martial traditions (p. 24-25). None of these assertions can be empirically disproven, however the existence of a simpler and more durable explanation seems likely.

\footnotetext{
1 Tengu are commonly understood to be a kind of mountain-dwelling, anthropomorphic, trickster goblin with avian features (either an actual beak or a very long nose and wings) and they have come to be closely associated with early Buddhist ascetics/mystics. They are also said to possess extraordinary martial abilities that they can transmit to worthy human students, as is the case with the legend of Minamoto no Yoshitsune (Hansen, 2008, 213n6).

2 The Japanese term bugei is comprised of the ideograms for 'war' and 'skill/art' and is used here in reference to the classical martial traditions of Japan, as opposed to the modern budo, such as judo and kendo.

3 The protoceratops was a four-legged, horned dinosaur found in modern-day Mongolia.
} 
As far as interpretation of those narratives and ethnography available for Japan, data indicates that reliance on extrahuman forces (in the historical narrative, legends, and folklore, at any rate) is not always the product of anti-foreign or anti-imperial sentiments, however the presence or perceived presence of foreign threats does appear to cause intensification on a group scale. Shishida and Flynn (2013) provide three prime examples of historical cases in which the development of martial arts practice in Japan is directly linked with peaceful spiritual cultivation that has little, if anything, to do with foreign antagonism. The concept of supernatural martial power as a counter-force to domination by a hegemonic force is, however, clearly manifest in the riots and other group violence in late nineteenth and very early twentieth century China.

\section{2.- China}

While the most well-known of the nineteenth century violent groups is likely the Shenquan "Spirit Boxers," other organizations with similar methods of operation appeared both before and afterward, including the Big Sword Society and the Red Spears (Perry, 1984, p. 436-440). The Shenquan are of special importance here because:

The distinctive ritual of these Boxers was a type of spirit possession whereby in theory any member could become a god. Opening the door to universal deification, the ritual had important egalitarian implications. The Spirit Boxers, with few local gentry to restrain them, spread rapidly across the North China Plain, launching aggressive attacks against foreign targets in their midst (Perry, 1984, p. 436).

Neither the spiritual belief from which this manifestation sprang nor the physical arts that they practiced came into being solely as a result of perceived foreign threats, however, when triggered, intensification took place and what began as "self-defense organizations" became aggressively violent and centralized the importance of the supernatural (Perry, 1984, p. 435).

Of additional interest is the demographic makeup of such groups. As they were, to some extent, organized parties, historians have been able to accumulate an impressive quantity of information about the constitution of their membership and, consequently, the purposes of this inquiry are best served by remaining focused on those unique cults active during the preRevolutionary period of roughly 1880 to 1911 even though a larger body of historical data is available because, unfortunately, said data is almost entirely economic in nature. Perry notes that Western Henan province, for instance, saw more violent action from the Red Spears than did Northern Henan. The members in the west tended to be more "authoritarian" and came primarily from the ranks of "local bullies" and "demobilized soldiers" while those in the north were more likely to be land holders (Perry 1984, p. 440). Interesting, too, is that the lands in the west were under consolidated ownership while those in the north were more equally distributed (p. 440). This may have more complex implications when comparing power dynamics with other agrarian economies in which a small percentage of the population controlled most of the land, such as Caribbean slave colonies.

\section{3.- The Afro-Atlantic}

Robert Farris Thompson sums up the value of Afro-Atlantic martial arts as deriving "from a history of accomplished motion; that is, the movements allude to attack and defense, but at the same time they express historical essences of comradeship and spirit" (Thompson, 1987, p. 44). This dichotomous aesthetic - that the same thing is utilized for both leisure and serious combat-is supported by the historic record and requires that its history be considered in order for the connection between Afro-Atlantic martial arts and the supernatural to be more thoroughly understood.

"Historically, African martial culture was part of the African art of war" (Green \& White, 2010, p. 337). In the interest of both brevity and accuracy, this discussion will be limited to West Africa rather than attempting to cover the myriad traditions of an entire continent. The Yoruba, perhaps the most culturally influential ethnic group on the development of the diaspora, reflect the play/fight dichotomy in their festivals. During Agemo, a festival of "masked performance" honoring, 
in part, the trickster god, Esu, "the action surged back and forth between poles of joking and fighting, so that to get involved in Agemo was indeed to become a trickster" (Drewel, 1992, p. 113). Here, then, the arts of war and humor were one in the same.

The value placed on individual competence in improvisation appears to have a long history. As Yoruba lifeways were transferred to the New World, this emphasis on verbal combat and quickwittedness remained a core feature of festival. Says Abrahams, "The ability to contend effectively with words is, then, a social skill highly valued as such" (1983, p. 55). During some verbal contests that he observed the participants would shift their feet and punch the air (p. 61) and "a further activity of this sort was the well-known kalinda stick-fight dance" (p. 64). It is telling that Abrahams sees the stick fight as being on a spectrum that also contains verbal conflict and shadow boxing.

Even in the present day, Nigerian boxers in the Dambe tradition utilize magic amulets and other spells or prayers to gain a competitive edge (Green \& White, 2010, p. 337). This transition of war games to a sporting context does not seem to have altered many of the beliefs and practices surrounding them. Even when separated from their African geographic roots, the aesthetic of a play/fight dichotomy, ties to festival, and individual ritual competition are retained. Bolster (1997) notes several instances from the historical record in which African martial arts were clearly used in the New World.

The butting characteristic of black sailors at the turn of the nineteenth century survived the Middle Passage to take root in Afro-America from New England to Brazil. Seamen propagated the art as they traveled from one region to another, forging diasporic links through martial skill (Bolster, 1997, p. 119).

Regardless of which African culture is responsible for the dissemination of headbutting (Bolster maintains that one "Samba Jean," an expert on the subject, traces it to Kongo), it, like so many skills in the diaspora, became widespread and took on a new identity, "racially distinctive, it transcended other cultural and linguistic divisions among blacks" (Bolster, 1997, p. 120). Certainly the skill was used in unfriendly confrontations, but there are also numerous accounts of a sort of ritual game in which two combatants would butt one another like rams (p. 120).

In the Americas the accompanying ways by which one may access supernatural power seem to have followed a similar pattern of adaptation as both the martial and verbal arts. Abrahams suggests that a certain aesthetic "operating in dance and drama and other expressive forms... can be shown to have persisted" in the diaspora (1983, p. 26). This would appear to be the case when syncretic religions are considered. Again largely reflective of West African cultural influences, religions such as Vodun, Santeria, and Candomble represent the plasticity of these beliefs, just as the Afro-Atlantic martial arts have been subject to wide dispersion. Bolster suggests that the water imagery usually associated with the Yoruba orisha Yemaya provided African and Afro-American sailors with "an anchor for the soul safe from their masters' prying eyes" (1997, p. 66).

A prime example of the ways in which the various elements of music, festival, dance, play, and fight are integrated is the parallel Carnival celebrations. "The boismen of Trinibago, the capoeira dancer-combatants of Rio, and the Guardians of the Flame Mardi Gras Indians in New Orleans all march to the same agonistic pulses" (Abrahams et al., 2006, p. 51).

Likewise, Lewis (1992) writes of his time at a festival honoring the emancipation of slaves in Brazil on May thirteenth, 1888:

In addition to capoeira games, the other main activity of this festival was candomble, the African-Catholic religion characteristic of Bahia... I had seen several capoeira players also take turns playing drums for the candomble circle, to promote the descent of spirits into the heads of the dancing initiates (Lewis, 1992, p. xix).

Again, the festival occasion calls for a mixture of spiritual practice, play/fight, and music. Like Abrahams' observation of kalinda as a "stick-fight dance," capoeira is dichotomous in that it is at once play and combat, fight and dance. With music as an indispensable part of the capoeira setting, it's worth noting that "verbal dueling" is "still part of the capoeira esthetic, even if their elaboration is largely a thing of the past" (p. 155). The active community surrounding capoeira, 
then, has, over time, continued to engage the various aspects of Afro-Atlantic martial culture in ways echoed elsewhere throughout North America and the Caribbean.

Beyond the historical record, African-American folk narrative supports the value of cleverness in individual combat. In a narrative set during the plantation period in the southern United States two plantation masters purchase slaves and agree to pit the strongest of each camp against the other in a fight. The victor's owner is to receive a large sum of money. On the evening before the match one of the slaves expresses doubts about his ability to meet his opponent's strength and instead concocts a scheme by which to frighten him into forfeiting. The clever slave places an uprooted tree at the meeting site and hides its roots so it appears to have grown there. When the two parties meet, the clever slave feigns immense strength and pulls the rigged tree from the ground, thereby winning through intimidation (Green, 2009, p. 72-73).

In a story about the confrontation between an evil bird named Loggerhead and a hero called Old Witch Boy, the socially marginalized protagonist-in addition to being a witch, he also lives with only his grandmother-fashions a "special knife" from a piece of found tin and proceeds to kill the bird, freeing the town from its terror and winning for himself a wife and home (Abrahams, 1985, p. 232-233). The image of a knife with magic properties is interesting in that it draws on both the importance of martial skill in everyday life as well as the ubiquity of access to the supernatural. Old Witch Boy is one among a cast of characters who "inhabit places where humans and the spirit world interact" (p. 221).

With regards to the greater issue of group resistance to foreign encroachment, any number of violent uprisings connected with practitioners Afro-Atlantic martial arts took place in the nineteenth century, but one in particular is highly illustrative. During the Trinidadian Carnival celebration in 1881 the bands, working with and composed largely of stick fighters, staged a riot, assaulting the mounted police during what was supposed to have been a friendly musical competition (Riggio, 1998, p. 8). While not on the scale of a full-fledged revitalization movement and certainly not comparable to the Chinese boxer organizations with their systematized notions of supernatural backing in ousting non-local intrusion, the Carnival riot clearly shows an instance in which the martial arts were used as social tools by the weak in an effort toward social change.

\section{4.- Native America - Great Lakes and Great Plains}

At the beginning of the nineteenth century, in the Great Lakes region of the United States, the famous leader of a pan-tribal movement, Tecumseh, teamed with his brother Tenskwatawa to form a community based on the latter's prophecies (Cave, 2002, p. 665). Tenskwatawa's message was not unlike that of other Native leaders of spiritual movements, such as Handsome Lake, except that he suggested the abandonment of Euro-American ways would not only result in a supernatural expulsion of the whites from North America, but that such expulsion should be helped along through violence (p. 666).

The new religion was especially attractive to warriors, who abandoned the more peaceful communities en masse to join Prophetstown, the settlement that the brothers had established on the Wabash River (Edmunds, 1983, p. 274). As more people flocked to the encampment, food quickly became scarce and Tenskwatawa saw fit to request that the U.S. government provide for the people there (p. 271). While a period of peaceful relations followed, Governor William Henry Harrison maintained a suspicion that Tecumseh and Tenskwatawa were planning an offensive. "The suspicions voiced by Harrison and Wells were well founded. The Prophet and his warrior brother, no longer believing that peace with the United States was a viable option, now were waiting for the right time to strike" (Cave, 2002, p. 668).

What followed was a period of troop movement, fort burning, and general unpleasantness that culminated with the War of 1812. The Prophetstown episode is interesting in that it recalls, in an unusual way, a Shawnee folk tale recorded by Spencer in 1909 as told by Charles Bluejacket. The story is framed as a humorous explanation of how the wildcat came to have spots on its chest, but it may indicate something of strategy, as well. A wildcat pursues a rabbit through the woods until the rabbit hides inside a tree. The wildcat intends to wait for the rabbit to grow hungry such that it has to choice but to leave its hiding spot. The rabbit, understanding this, agrees to be eaten, but not raw, 
and so the wildcat builds a fire on which to roast his quarry. When the coals are ready for cooking, the rabbit kicks them in the wildcat's face and dashes away (Spencer, 1909, p. 323).

It would be too presumptive to suggest that the brothers heard a rendition of this tale and intentionally followed a similar tactic, but as a part of the society in which they were enculturated the general idea of the rabbit's tactic in overcoming its pursuer may very well have been a part of the core knowledge available. If nothing else, the story indicates that the Shawnee of the time, like their African-American contemporaries, valued cleverness over brawn, placing the trickster in a victorious position.

Later, and on a larger scale, the U.S. government policies to suppress Native dances came about due, among other reasons, to the fear of "passions" being raised in the warriors of a given reservation (Ellis, 1999, p. 137). Among the Ponca, for instance, these warriors were members of a society that served more social functions than simply preparing for and engaging in warfare. One such function was the use of public dances as a means of supporting the needy (p. 137). It would seem that the Indian agents responsible for the effort to stamp out tribal dances were, to some extent, aware that doing so would also defang the martial spirit associated with them.

Within Cheyenne society the warrior fraternity known as the Dog-Men Society or "Dog Soldiers" was responsible for certain aggressive political action as well as the maintenance of decorum (Green, 2010, p. 653). The members are probably most well-known for the practice of staking a sash or rope made of buffalo hide to the ground during a desperate moment of combat with the understanding that he would either die on that spot or remain until a fellow member of the society removed the stake. These warriors employed extrahuman aid in the form of a feathered headdress that allowed the wearer "supernatural protection during battle" (p. 653). The Dog-Men eventually accrued such influence and prestige that they took to living apart from the bulk of the Cheyenne and reversed the historically matrilocal customs, causing members' families to remain with the group (Moore, 1974, p. 332).

Turner (2003) notes the importance to the Cheyenne specifically-and to other low-power societies generally - of ritualizing the preparation and conduct of warfare in a spiritual and/or religious paradigm. Revitalization and retribution movements like the Ghost Dance were attractive to the Cheyenne and other tribes because they allowed for the legitimization of practices like those of the Dog-Men, who, before each battle, prepared themselves both physically and socially as if they had already died. They sang their death songs, dressed in finery as for a funeral, and segmented themselves as a collective from the rest of the tribe. Although an attempt to criticize the concept of a civilizing process as the sole means of transitioning from personal, violent conflict to the discipline of sport (and related activities) as a proxy for warfare in an age of democratization, Turner's argument best serves to highlight the extent to which a collective belief in the supernatural as a source of legitimate martial power has acted as an effective psychological mechanism for the enactment of social efforts.

The Plains tribes of North America experienced hostility from a foreign power in such a unique and drawn-out manner that it is difficult to pinpoint a specific moment in time at which a nativistic or nationalistic movement intersected with calls for supernatural power to utilize fighting arts in the interest of social change. One could say that such responses were taking place more or less constantly throughout the U.S. government's expansion westward. Certainly revitalization movements became more commonplace during the nineteenth century, as exemplified by the Prophetstown situation and the widespread Ghost Dance movement.

\section{5.- India}

At the end of the nineteenth century, on the Indian subcontinent, the indigenes were experiencing annexation by the British. In a comparison of popular depictions of Hindu deities through time, a pattern shift toward martial imagery emerged (Kaur, 2007, p. 76). This imagery became more prevalent throughout the eighteenth century as orders of warrior ascetics parallel to the Japanese sohei rose in numbers (Lorenzen, 1978, p. 64).

From before the Muslim conquest of India there are legendary accounts of clashes between Brahmin priests and rulers of the state, often resolved through either the intervention of outside 
supernatural beings or the intentional use of magic. While not strictly confined to the timeframe of this study, such narratives are valuable here for two reasons: there is a lack of material otherwise directly linking martial action with the supernatural and these narratives form part of the inherited social fabric of those in the region at the time under consideration.

One example of this from the Rajatarangini has a ruler by the name of Gonanda III dealing with excessive amounts of snow which are being dropped on his people by divine beings as punishment for ignoring traditional Hindu practices in favor of Buddhism (Lorenzen, 1978, p. 66). Predictably, Gonanda III orders his people to change their ways and the snows end. Another such instance is the account of a battle between a King Sudhanvan and his sponsored religious order led by philosopher Sankaracarya against the Kapalika tantric yogis. The king makes an offensive statement toward the yogis, who meet his army of militant Brahmins with their own extraordinary abilities. An epic clash ensues and is ultimately concluded when the yogis call on the god Bhairava, whose earthly representation turns out to be the opposing Sankaracarya, and eliminates the yogis (Lorenzen, 1978, p. 65).

The latter of these tales is particularly interesting because it features not only extrahuman forces in organized combat, but also because the monastics themselves are serving in a militant fashion. This is of notable difference to tales of any given ascetic visiting violence in the course of an isolated incident. Rather, the supernatural assistance given here clearly indicates that such nonhuman entities approve of institutional uses of martial skill.

The extent to which the legends influenced the use of force by religious orders or vice versa is unclear, however there is historical evidence that such behavior occurred. As early as the eighteenth century the British Raj in India saw fit to close down the armed forces of the Mughals in the interest of forming an explicitly British military at least in part because of questions pertaining to the loyalty of native troops who were also of Sufi and Hindu faiths. "The question of the composition of this group of soldiers is important; it also brings in the complicated problem of the connotations of Fakirs and Sannyasis in the society of Bengal during the 18th century" (Dasgupta, 1982, p. 46).

More recently, a resurgence of a traditional (or seemingly-traditional) family of fighting arts has taken place. Zarrilli found that the Indian martial art called kalarippayattu has ties with certain types of yogic practice and, once mastered, allows the adherent "the power to call and to dismiss the deities of the kalari [practice hall]" (1989, p. 1289). The ability to perform at a masterful level in both unarmed and armed practice and combat is seen as a feat of supernatural power (sakti) and an indication of the spiritual accomplishments of the performer (p. 1303).

Here the intervention of supernatural forces is almost entirely at the command (or request) of the practitioner, which echoes the martial practices of the Shenquan and the Red Spears in so far as personal achievement of the extraordinary is considered a possible and praise-worthy goal. Like the capoeiristas in Brazil and stick fighters in Trinidad, the direct involvement of spirits on the fighter's behalf-including possession-is a positive occurrence and serves to shift praise from the performer to the extrahuman agent in the event of a highly skillful performance.

\section{4.- Discussion}

One motif that appears in several of the above cases in which a smaller power is struggling against a larger, often foreign, one in the interest of social change is that of "the invulnerable body" (Wilson et al., 2010, p. 622). Wilson et al. (2010), identify this as a trope of such situations, noting that physical and psychological training can be as much about politics as it is outright combat, "Martial art thus provides the means for both contesting and consolidating authority. The ideals and values of the martial arts are not merely via overt confrontation, but also through the constitution of subjects and subjectivities via sustained disciplinary practice" (p. 624).

For some groups political action seems to have taken precedence over spiritual and/or religious austerity with regards to the rehearsal and application of the fighting arts. This was certainly the case with the Japanese sohei who, while no doubt formidable warriors, "acted no differently than their secular counterparts, nor do they appear to have been motivated by a 
religious rhetoric qualitatively different from other ideologies condoning violence" at the time (Adolphson, 2007, p. 162). Rather, their value seems to be as part of an invented tradition. "They now seem to represent something more positive in local communities, in contrast to their reputation among historians" (p. 152).

Even as the Benkei legend has grown to exemplify modern Japanese ideals of loyalty, the question of being simultaneously a religious adherent and a fighting man does not appear to cause any conflict ideologically. At the same time, though, there is not significant evidence that the sohei saw themselves as having any more or less access to supernatural power than their contemporaries. This is in direct contrast to the Indian cases, in which religious or pseudo-religious ascetic-warriors appear to be fully justified and, indeed, driven by the will of supernatural forces. Likewise, in slave colonies of the Afro-Atlantic it is clear that at least some religio-spiritual elements were present in the practice of martial traditions in such ideationally-driven conflict settings. Such social antagonism can is evident in terms of performance and sporting traditions as a proxy for outright warfare, with perhaps the most illustrative such case found in the Dragon Dance of Tu Village (Tu et al., 2013). The Tu villagers, in performing their local memorial dance during the Spring Festival, are also shown to be enacting potentially-contentious social hierarchies and historically-situated conflicts with other groups. As with highly performative martial traditions found in Atlantic slave colonies, the physical virtuosity displayed by the dancers provides an outlet for otherwise more violent enactment of such frustration as associated with spiritual (and sometimes biological) ancestors.

The issue of supernatural martial power among nineteenth century Shawnee and other Plains peoples is difficult to decipher in comparison with other groups attempting to resist larger foreign invaders and colonial forces because of the drawn-out nature of the conflict. It can reasonably be said that movements like the Prophetstown religion and the Ghost Dance were attempts to access the supernatural as a means of social change, however the extent to which those attempts intersected with martial behavior remains unclear, particularly due to the decline of warrior societies like the Dog-Men, but also because such societies took part in more than just soldierly activities. It does seem to have been the case that the warriors in Tenskwatawa's camp, at some point, probably believed themselves invulnerable to the U.S. soldiers' weapons thanks to the supernatural influence of the Prophet (Cave 2002, p. 653). This is most readily comparable to the Spirit Boxers, who believed themselves the recipients of special bodily strength given similar circumstances as a foreign, hegemonic power was in the process of encroaching on native territory and autonomy.

\section{5.- Conclussions}

Throughout the Afro-Atlantic, in turn-of-the-century China, and in nineteenth century Japan there are definite cases of the supernatural being called upon for martial purposes. In the case of China and the Americas the extrahuman actors are primarily manifest through practitioners' bodies in the form of prodigious skill. In these instances the group appears to have placed a premium on individual development in the interest of accomplishing the group's revolutionary goals. In Japan this was less distinctly the case, however Atsutane's writing gives a good indication that the zeitgeist was of a mind to call on uniquely Japanese supernatural entities to somehow assist the populace in ridding themselves of too much foreign influence. A similar sentiment appears to have prevailed among the Chinese social/martial organizations, however with more proactive results. Plantations and slave colonies in the Americas populated by Africans and their descendants served as places of cross-cultural pollination that resulted in unique beliefs and practices, socially, religiously, and physically. The emergent cultures fostered a sensibility that allowed for revolts against the planters and those under their employ, especially during festival.

No universal conclusions can be drawn from the above, however a pattern of rebellion and rioting appears in some cultures when a mixture of fighting discipline, religious or spiritual fervor, and the presence or threat of foreign control is introduced. A more comprehensive global comparison of similar situations, in keeping with the cross-cultural comparison model, may lead to more conclusive findings. 


\section{References}

Abrahams, R. D. (1983). The man-of-words in the West Indies. Baltimore: Johns Hopkins University Press.

Abrahams, R. D. (1985). African American folktales. New York: Pantheon.

Abrahams, R. D., Spitzer, N., Szwed, J. F., \& Thompson, R. F. (2006). Blues for New Orleans: Mardi Gras and America's Creole soul. Philadelphia: University of Philadelphia Press.

Adolphson, M. S. (2007). The teeth and claws of the Buddha. Honolulu: University of Hawai'i Press.

Bolster, J. W. (1997). Black jacks. Cambridge: Harvard University Press.

Cave, A. A. (2002). The shawnee prophet, tecumseh, and tippecanoe: a case study of historical mythmaking. Journal of the Early Republic, 22(4), 637-673.

Dasgupta, A. (1982). The fakir and sannyasi rebellion. Social Scientist, 10(1), 44-55.

Drewel, M. T. (1992). Yoruba ritual. Indianapolis: Indiana University Press.

Edmunds, R. D. (1983). Tecumseh, the Shawnee prophet, and American history: a reassessment. The Western Historical Quarterly, 14(3), 261-276.

Ellis, C. (1999). "We don't want your rations, we want this dance": the changing use of song and dance on the southern plains. The Western Historical Quarterly, 30(2), 133-154.

Ember, C. R. \& Ember, M. (2001). Cross-cultural research methods. New York: AltaMira Press.

Fine, G. A. \& Ellis, B. (2010). The global grapevine. New York: Oxford University Press.

Friday, K. \& Seki, H. (1997). Legacies of the sword. Honolulu: University of Hawai'i Press.

Galbraith, J. S. (1982). Appeals to the supernatural: African and New Zealand comparisons with the Ghost Dance. Pacific Historical Review, 51(2), 115-133.

Green, T. A. (2003). Introduction. In T. A. Green \& J. R. Svinth (Eds.), Martial arts in the modern world (pp. xi-xiii). Westport, CT: Praeger.

Green, T. A. (2010). Plains Indian Warrior Societies. In T. A. Green \& J. R. Svinth (Eds.), Martial Arts of the World (pp. 651-657). Santa Barbara: ABC-CLIO.

Green, T. A. (Ed.) (2009). African American folktales. Westport, CT: Greenwood Press.

Green, T. A. \& Svinth, J. R. (2010). Belief systems. In T. A. Green \& J. R. Svinth (Eds.), Martial arts of the world (pp. 331-332). Santa Barbara: ABC-CLIO.

Green, T. A. \& White, E. (2010). Belief systems: Africa. In T. A. Green \& J. R. Svinth (Eds.), Martial arts of the world (pp. 332-338). Santa Barbara: ABC-CLIO.

Gump, J. O. (1994). The dust rose like smoke. Lincoln: The University of Nebraska Press.

Hansen, W. (2008). When tengu talk. Honolulu: University of Hawai'i Press.

Kaur, R. (2002). Martial imagery in Western India: The changing face of Ganapati since the 1890s. South Asia: Journal of South Asian Studies, 25(1), 69-96.

Klapp, O. E. (1954). The clever hero. The Journal of American Folklore, 67(263), 21-34.

Knutsen, R. (2011). Tengu: the shamanic and esoteric origins of the Japanese martial arts. Kent, UK: Global Oriental.

Lewis, J. L. (1992). Ring of liberation. Chicago: University of Chicago Press.

Lorenzen, D. N. (1978). Warrior ascetics in Indian history. Journal of the American Oriental Society, 98(1), 61-75.

Moore, J. H. (1974). Cheyenne political history, 1820-1894. Ethnohistory, 21(4), 329-359.

Perry, E. J. (1984). Collective violence in China, 1880-1980. Theory and Society, 13(3), 427-454.

Riggio, M. (1998). Resistance and identity: Carnival in Trinidad and Tobago. The Drama Review, 42(3), 7-23.

Said, E. W. [1978] (1994). Orientalism. New York: Random House.

Shishida, F. \& Flynn, S. M. (2013). How does the philosophy of martial arts manifest itself? Insight from Japanese martial arts. Ido Movement for Culture. Journal of Martial Arts Anthropology, 13(3), 29-36.

Spencer, J. (1909). Shawnee folk-lore. The Journal of American Folklore, 22(85), 319-326.

Svinth, J. R. (2010). Social uses of the martial arts. In T. A. Green \& J. R. Svinth (Eds.), Martial arts of the world (pp. xix-xxi). Santa Barbara: ABC-CLIO.

Thompson, R. F. (1987). Black martial arts of the Caribbean. Review: Latin American Literature and Arts, 37, 44-47.

Tu, C., Green, T. A., Zheng, G., \& Feng, Q. (2013). Dragon Dance in Tu Village: Social cohesion and symbolic warfare. Ido Movement for Culture. Journal of Martial Art Anthropology, 13(1), 1-9. 
Turner, B. (2003). Warrior charisma and the spiritualization of violence. Body \& Society, 9(4), 93108.

Wilson, L., Facal, G., Grave, J. M., \& Green, T.A. (2010). Political conflict and the invulnerable body. In T. A. Green \& J. R. Svinth (Eds.), Martial arts of the world (pp. 622-625). Santa Barbara: ABCCLIO.

Zarrilli, P. B. (1989). Three bodies of practice in a traditional South Indian martial art. Social Science \& Medicine, 28(12), 1289-1309.

\section{Author's biographical data}

Jared Miracle (United States), is a Ph.D. candidate in the Department of Anthropology at Texas A\&M University, College Station, Texas, USA. His dissertation research focuses on fighting arts in a transnational and cross-cultural context. He has been a martial artist since childhood, was a boxer at Japan's KTT Gym under Naito Toshihiro, and studies Shinkage-ryu swordmanship with Watanabe Tadashige. His research interests include East Asian folk narratives, history, religion and the supernatural, dueling, and AsianAmerican culture. E-mail: jaredmiracle@tamu.edu. 